\title{
Product Quality Improvement Through Training on Tempeh Packaging at PRIMKOPTI SWAKERTA Semanan
}

\author{
Anik Nur Habyba ${ }^{1, a)}$, Indah Permata Sari'), Dorina Hetharia ${ }^{1)}$ and Dedy Sugiarto ${ }^{2)}$ \\ 1Department of Industrial Engineering, Faculty of Industrial Technology, Universitas Trisakti, Jakarta, \\ Indonesia \\ ${ }^{2}$ Department of Informatics Engineering, Faculty of Industrial Technology, Universitas Trisakti, Jakarta, \\ Indonesia \\ a)Corresponding Author: anik@trisakti.ac.id
}

\begin{abstract}
Packaging is the first thing seen in a product and today many companies are focused on developing product packaging designs to compete in the market. The improvements in the type and design of packaging can be done PRIMKOPTI SWAKERTA Semanan to maintain customer loyalty. The purpose of this dedication is to provide knowledge of more environmentally friendly packaging alternatives to support the sustainable development of the tempeh industry and its processing in Semanan. Devotional activities begin with an introductory survey and then continue with training conducted online with the devotional team and tempeh craftsmen. The delivery of several training materials was done in parallel related to quality improvement, some of these materials such as the application of Good Manufacturing Practice, maintenance of production machines and food packaging. The survey results showed that $66.7 \%$ of craftsmen use clear plastic with a simple design and some do not even use labels. The remaining $33.3 \%$ of tempeh craftsmen use a combination of aluminium foil and plastic packaging. Alternative solutions are provided in improving the quality of tempeh products through banana leaf packaging. Banana leaves help the process of fermentation on tempeh and also increase consumer interest in buying because it is preferred. Kraft paper packaging is recommended for use because it can reduce the risk of rancidity on tempeh chips and extend the shelf life. Semanan tempeh makers can use this food packaging alternative to attract back consumers' interest that decreased during the pandemic..
\end{abstract}

Keywords: Tempeh, food packaging, product quality

\section{INTRODUCTION}

PRIMKOPTI SWAKERTA (Primary Indonesian Tempeh and Tofu Cooperative) is based in the Semanan KOPTI Complex, Kalideres District, West Jakarta. Around 1200 tempeh producers and seven tofu factories are members of this cooperative. Most of the tempeh craftsmen who are incorporated are still home-based industries that are able to process an average of $50 \mathrm{~kg}$ of soybeans into tempeh every day. High product demand makes product quality crucial so that customer satisfaction can be achieved. During the pandemic, tempeh craftsmen in Semanan suffered losses due to a decline in demand up to $55 \%$ from normal conditions. One of the problems faced is product packaging that is unattractive, less informative and does not yet have a halal logo from the Indonesian Ulema Council and a home industry food production certificate from the Food and Drug Supervisory Agency (Iskandar et al., 2021). Traditionally, the packaging is used to protect products that are in the process of distribution, transportation, or storage, but nowadays, packaging has become an effective tool for communicating with customers (Wyrwa \& Barska, 2017). Packaging can also affect the impression of product quality that customers see.

Product quality is not only assessed from product characteristics but also product appearance and packaging. Packaging is the first thing seen in a product and currently many companies are focusing on developing product packaging designs to compete in the market. Packaging is considered necessary in product marketing and is very important to attract customer buying interest with packaging (Ahmed et al., 2015). Previous research has shown that packaging is a container for the product being sold and affects how customers feel when they first see the product. The packaging design must also pay attention to the customer's 
impression, and the product can affect them (Habyba et al., 2019). The packaging of tempeh and tempeh chips at PRIMKOPTI Semanan needs to pay attention to this aspect to attract buyers.

Apart from the graphic design side, the information contained on the packaging, packaging materials are also important things that need to be considered. Packaging materials contribute to environmental problems not only because they become waste but are also related to the consumption of resources and energy in their manufacture (Wikström et al., 2014). Subsequent packaging improvements are in terms of appearance and must consider materials that are more environmentally friendly or require less resources and energy in their manufacture. Most of the craftsmen still use clear plastic as the main packaging material. Plastic has an impact on the surrounding environment. The assumption that environmentally friendly packaging is expensive is also still an obstacle for industry players to replace processed Tempeh packaging into more environmentally friendly packaging. Alternative packaging that is more environmentally friendly can be used so that Semanan's environmental sustainability can also be achieved. Based on the problems that exist in PRIMKOPTI SWAKERTA Semanan.

\section{METHOD}

Tempeh packaging training activities for tempeh and tofu craftsmen who are members of PRIMKOPTI SWAKERTA Semanan was held online on February $25^{\text {th }}, 2021$. Participants who joined this community service activity (PkM) totaled 20 craftsmen, but due to technological and network constraints, only 10 people could attend the Zoom meeting in full. The participants who attended were chaired by the secretary of PRIMKOPTI "SWAKERTA" West Jakarta, namely Mr. KR Handoko Mulyo.

The series of activities began with a preliminary survey exploring the problems faced by PRIMKOPTI SWAKERTA Semanan. The preliminary survey carried out on October $12^{\text {th }}, 2020$, can be seen in Figure 1. The training event began with a speech from the PRIMKOPTI secretary in Figure 2, then continued with the delivery of several training materials carried out in parallel concerning quality improvement, some of these materials such as the implementation of Good Manufacturing Practice, maintenance of production machines and food packaging. This PkM was also carried out in collaboration with the Department of Informatics and Mechanical Engineering, Faculty of Industrial Technology, Universitas Trisakti.

\section{RESULTS}

The training results can be seen that the limitations of technology make tofu and tempeh craftsmen unable to absorb the material well. Only 10 people (45.5\%) participated in the training to the end of the training for 22 tempeh tofu craftsmen. The results of the questionnaire show that technological constraints are also a weakness of the craftsmen. A total of 22 registered craftsmen, only 2 people $(0.91 \%)$ were female, the rest $99.09 \%$ were male. The tempeh and tofu craftsmen in Semanan are dominated by the home industry, which is the main occupation of the heads of families.

Based on the results of confirmation through the questionnaire, it can be seen that most of the craftsmen still rely on tempeh and its processed products as the main product. In addition, no one has marketed their products online or through e-commerce. Regarding packaging issues, most craftsmen only use a few banana leaves and are dominated by plastic as the primary packaging material for tempeh and its products. Through discussions during training, tempeh craftsmen understand that consumers prefer banana leaf packaging because of the many benefits. Craftsmen currently prefer to use plastic because it can minimize production costs without considering customer desires. In addition, the craftsmen also assume that the quality of tempeh produced from any type of packaging will be the same.

The packaging of tempeh chips used by Semanan tempeh craftsmen uses clear plastic and aluminium foil, an example of the packaging can be seen in Figure 5. Most of the 66.7\% craftsmen use clear plastic with simple designs and some do not even use labels. The remaining 
33.3\% of tempeh craftsmen use a combination of aluminium foil and plastic packaging. The tube-shaped packaging has a more modern design and already represents the brand and product information required for the ingredient composition and expiration date. MSME Mutiara Semanan only owns this type of packaging. In addition, there is also a black standing punch packaging made from an alloy of aluminium foil and plastic.

\section{DISCUSSION}

Problems with the quality of tempeh and its processing at PRIMKOPTI SWAKERTA Semanan are not only influenced by conventional machines so that product hygiene is difficult to maintain, raw materials are of poor quality or work areas are less comfortable, but also caused by product storage. The results of the previous service, namely the define, measure, analysis, improve and control (DMAIC) approach in controlling the quality of tempeh, it is known that the types of defects in tempeh products are also influenced by packaging and storage. Some types of defects, namely tempeh with holes eaten by animals, sour taste in tempeh due to the imperfect mushrooming process (Wilujeng \& Wijaya, 2019). This service has not discussed solutions that can be done to overcome the types of defects caused by product packaging.

Banana leaf packaging can overcome the type of defect in tempeh acid when used as tempeh packaging. The sour taste caused by the imperfect fermentation process can be prevented by adding banana leaf packaging. Banana leaf packaging in addition to making a different tempeh fragrance can also help the mushrooming process. In addition, banana leaves are also safe and biodegradable (Sucipta et al., 2017). In addition, a study showed that tempeh with banana leaf packaging had a higher protein content of $44.77 \%$ compared to plastic packaging, which was $41.38 \%$.(Salim et al., 2017). These results support previous research, that the mushrooming process in tempeh greatly affects the protein content of tempeh. The packaging factor determines the reaction between tempeh and packaging components, therefore banana leaves are better than plastic (Radiati \& Sumarto, 2016). These reasons require the tempeh craftsmen in Semanan to reuse banana leaf packaging in order to maintain customer loyalty. Today's customers are much more educated about the benefits of a product so that buying interest is influenced by low prices and product quality. An example of the use of banana leaves in tempeh packaging can be seen in Figure 6.

Most of the tempeh chips produced by Semanan tempeh craftsmen still use clear plastic. This packaging can be replaced with a combination of kraft paper which is widely used today. Examples of packaging can be seen in Figure 7. Kraft paper is a type of paper that is strong and the price is relatively cheap. This paper can be resistant to oil or water when coated with wax paper, parchment or wax. Kraft paper can also protect against gases and volatile compounds by combining it with foil and plastic layers (Sucipta et al., 2017). This can prevent the tempeh chips from being damaged longer. Tempeh chips which contain fat are very susceptible to rancidity, namely changes in the smell and taste of tempeh which are not liked by consumers (Maharani et al., 2012). Packaging from kraft paper will protect tempeh chips from rancidity longer because it is closed and protects from sunlight. Kraft packaging can protect tempeh chips better than clear plastic and is more environmentally friendly.

\section{CONCLUSIONS AND RECOMMENDATIONS}

This service provides an alternative to plastic packaging that tempeh craftsmen and their products have used. Banana leaf packaging can be used to improve the quality of tempeh such as higher protein content and a more optimal tempeh mushrooming process. Tempeh chips packaging, which primarily uses plastic packaging, can use packaging made of kraft paper which can prevent rancidity. Quality products are currently more in demand than cheap prices. Tempeh craftsmen in Semanan have received this knowledge from the PkM that has been implemented. Furthermore, assistance for simple and attractive kraft packaging designs can be carried out along with the management of the MUI and SP-IRT halal logos from BPOM. 


\section{ACKNOWLEDGMENTS}

This work was supported by Faculty of Industrial Technology and Community Service Institute of Universitas Trisakti. This work also received funding by Universitas Trisakti in the academic year 2020/2021. In addition, the authors also pay homage the tempeh and tofu craftsmen at PRIMKOPTI SWAKERTA Semanan who have been willing to work together to implement this service

\section{REFERENCES}

Ahmed, RR, Parmar, V., \& Amin, MA (2015). Impact of Product Packaging on Consumer's Buying Behavior. European Journal of Scientific Research202X European Journal of Scientific Research, 16, 35-42. https://doi.org/10.13140/2.1.2343.4885

Habyba, AN, Delfitriani, \& Djatna, T. (2019). An affective design for jenang packaging in Indonesia. IOP Conference Series: Earth and Environmental Science, 230(1). https://doi.org/10.1088/1755-1315/230/1/012030

Iskandar, J., Busnetty, I., \& Murwonugroho, W. (2021). Increasing Semanan Tofu Marketing Through Drive Thru Service Platforms. PKM Journal: Community Service, 04(04), 423433.

Maharani, DM, Bintoro, N., \& Rahardjo, B. (2012). Kinetics of Rancidity Changes in Fried Peanuts During Storage. Agritech: Journal of the Faculty of Agricultural Technology UGM, 32(1), 15-22. https://doi.org/10.22146/agritech.9651

Radiati, A., \& Sumarto, S. (2016). Analysis of Physical Properties, Organoleptic Properties, And Nutritional Content Of Tempeh Products From Non-Soy Beans. Journal of Food Technology Applications, 5(1), 16-22. https://doi.org/10.17728/jatp.v5i1.32

Salim, R., Zebua, ET, \& Taslim, T. (2017). Analysis of the Type of Packaging Against Protein Content and Water Content in Tempeh. Journal of Catalysts, 2(2), 106-111. https://doi.org/10.22216/jk.v2i2.22531

Sucipta, IN, Suriasih, K., \& Kenacana, PKD (2017). Food Packaging Study of Safe, Convenient, Effective And Efficient Packaging. Denpasar, Universitas Udayana Press, 1-178.

Wikström, F., Williams, H., Verghese, K., \& Clune, S. (2014). The influence of packaging attributes on consumer behavior in food-packaging life cycle assessment studies - $A$ neglected topic. Journal of Cleaner Production, 73, 100-108. https://doi.org/10.1016/j.jclepro.2013.10.042

Wilujeng, FR, \& Wijaya, T. (2019). Application of the DMAIC Method for Quality Control in Tempeh Semanan SMEs. Proceedings of the \#1 Young Intellectuals Seminar, Innovation in Science, Technology and the Arts in Planning and Design of the Built Environment, April, 266-271.

Wyrwa, J., \& Barska, A. (2017). Packaging as a Source of Information about Food Products. Procedia Engineering, 182, 770-779. https://doi.org/10.1016/j.proeng.2017.03.199 


\section{APPENDIX}

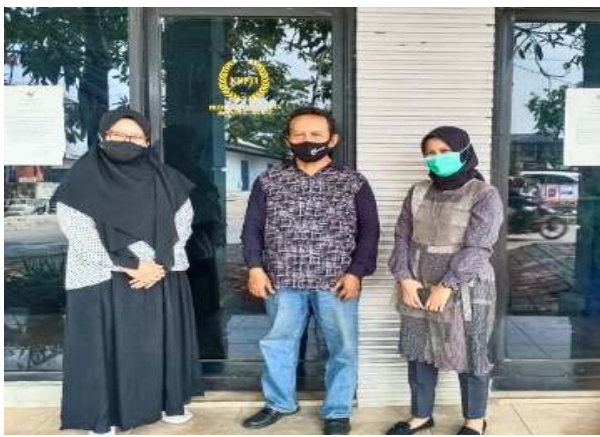

Figure 1. Photo of the Preliminary Survey with the Secretary of PRIMKOPTI SWAKERTA SEMANAN

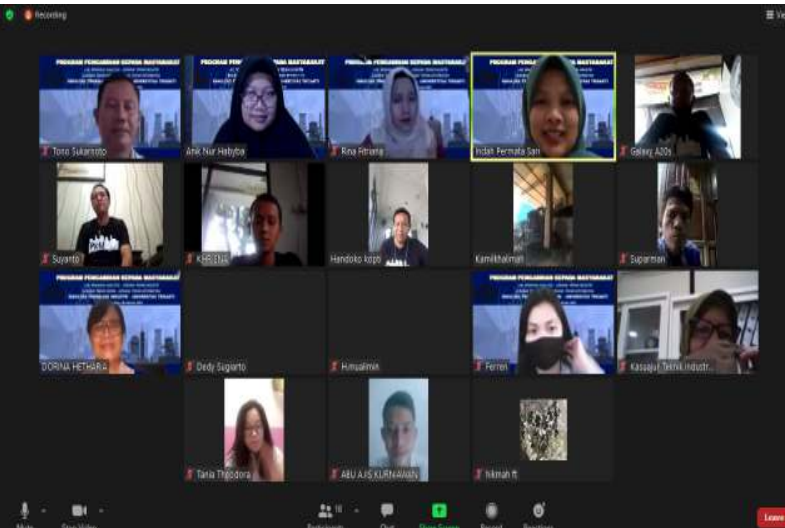

Figure 3. Group Photo of Participants and PkM Committee

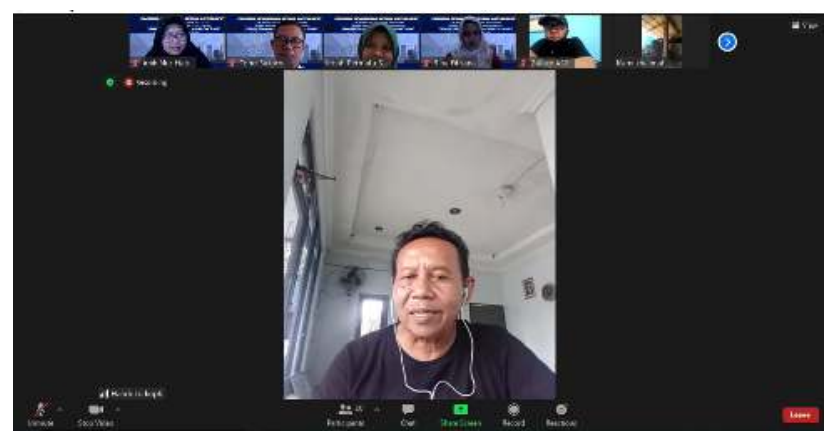

Figure 2. Opening Speech from the Secretary of PRIMKOPTI SWAKERTA SEMANAN

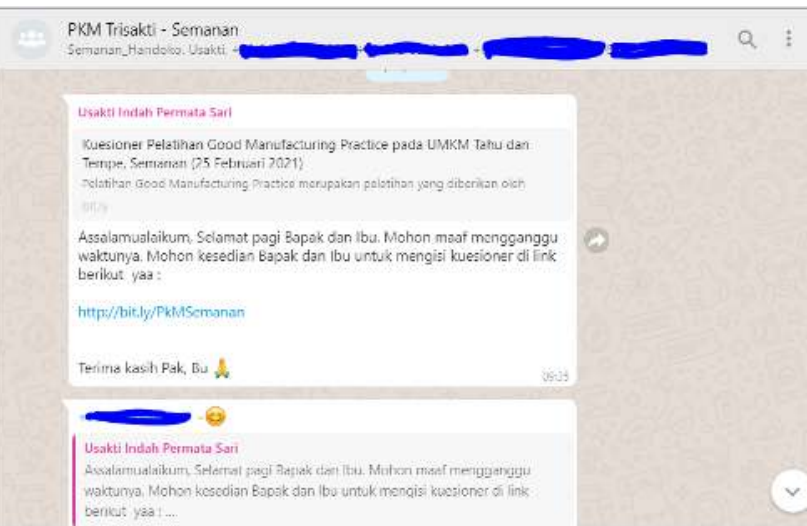

Figure 4. Whatsapp Group as a means of information with tempeh craftsmen
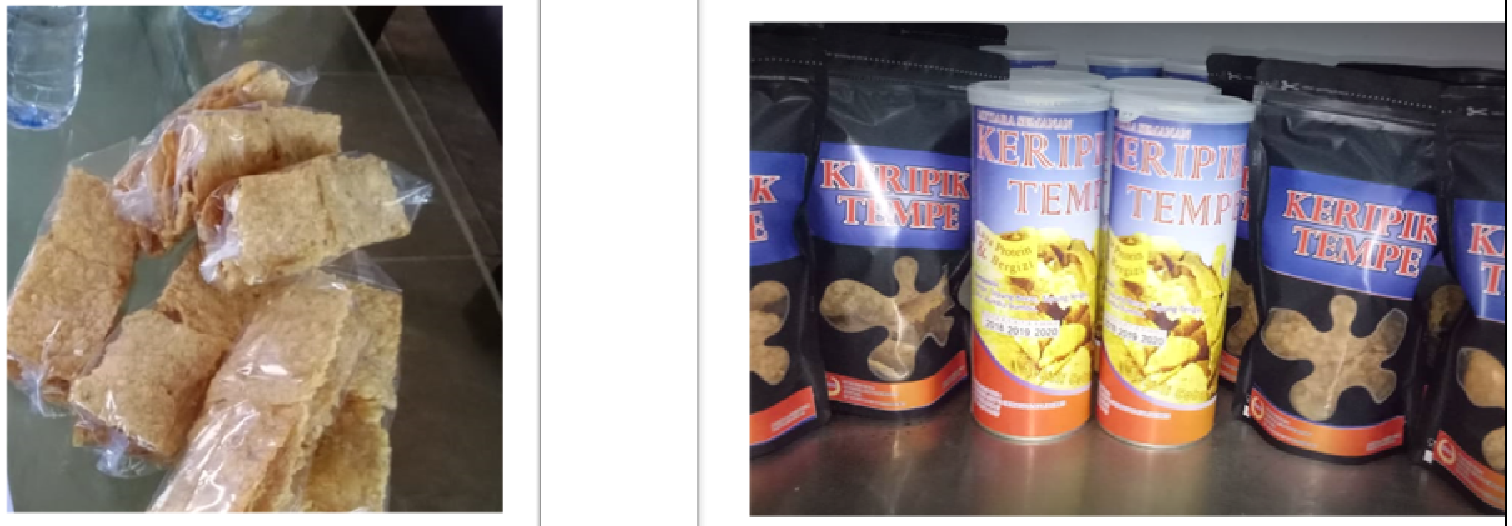

Figure 5. Example of Semanan Tempeh Chips Packaging 


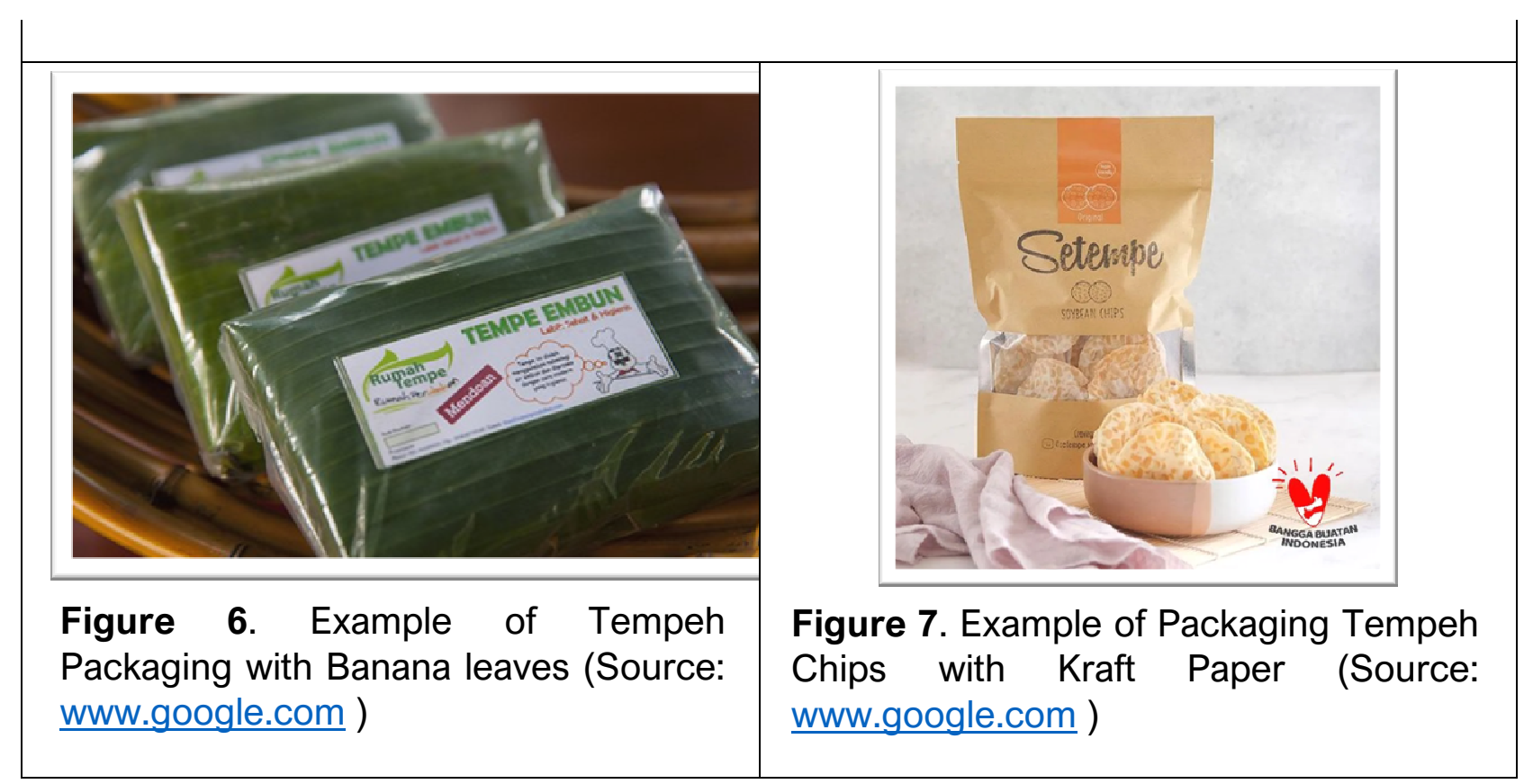

